\title{
Association of three single nucleotide polymorphisms of the E-cadherin gene with endometriosis in a Chinese population
}

\author{
Kang Shan, Ma Xiao-Wei, Wang $\mathrm{Na}^{1}$, Zhang Xiu-Feng ${ }^{1}$, Wen Deng-Gui ${ }^{2}$, Guo Wei ${ }^{1}$, \\ Zhang Zheng-Mao and Li Yan ${ }^{1}$ \\ Department of Obstetrics and Gynecology, Fourth Hospital, Hebei Medical University, Shijiazhuang 050011, China, \\ ${ }^{1}$ Department of Molecular Biology, Hebei Cancer Institute, Hebei Medical University, Jiankanglu 12, Shijiazhuang \\ 050011, China and ${ }^{2}$ Department of Epidemiology, Hebei Cancer Institute, Shijiazhuang 050011, China
}

Correspondence should be addressed to Li Yan; Email: lykx1962@yahoo.com.cn

\begin{abstract}
Endometriosis, one of the most frequent diseases in gynecology, is a benign but invasive and metastatic disease. The altered expression of E-cadherin may play an important role in developing endometriosis. In this paper, we discuss the association of three single nucleotide polymorphisms (SNPs) on the E-cadherin gene and risk of endometriosis. We examined the genotype frequency of three polymorphisms in 152 endometriosis patients and 189 control women. There was a significant difference in the frequency of the E-cadherin $3^{\prime}$-UTR $C \rightarrow$ T genotypes between endometriosis and controls $(P=0.01)$. The frequency of the $C$ allele in patients $\mathbf{( 7 1 . 1 \% )}$ was significantly higher than in the controls $(63.8 \% ; P=0.04)$. When compared with the $\mathrm{T} / \mathrm{T}+\mathrm{T} / \mathrm{C}$ genotypes, the $\mathrm{C} / \mathrm{C}$ genotype had a significantly increased susceptibility to endometriosis, with an adjusted odds ratio of 1.79 (95\% confidence interval=1.17-2.76). No significant difference was found between endometriosis and control women on two polymorphisms $(-160 \mathrm{C} \rightarrow \mathrm{A},-347 \mathrm{G} \rightarrow \mathrm{GA})$ at the gene promoter region of E-cadherin. The $-160 \mathrm{C} \rightarrow \mathrm{A}$ and $-347 \mathrm{G} \rightarrow \mathrm{GA}$ polymorphisms displayed linkage disequilibrium $\left(D^{\prime}=0.999\right)$. The $-160 \mathrm{~A} /-347 \mathrm{GA}$ haplotype was only detected in endometriosis patients $(2 \%)$. These data show a relation between the E-cadherin $3^{\prime}$-UTR C $\rightarrow$ T polymorphism, the $-160 \mathrm{~A} /-347 \mathrm{GA}$ haplotype of two promoter polymorphisms and risk of endometriosis, suggesting a potential role in endometriosis development, at least in North Chinese women.

Reproduction (2007) 134 373-378
\end{abstract}

\section{Introduction}

Endometriosis is one of the most frequent diseases in gynecology. The etiology and pathogenesis of this disease, defined as the ectopic location of endometrium-like glandular epithelium and stroma outside the uterine cavity, is unclear to date. Clinical observations have led to the assessment that endometriosis is benign gynecologically, but an invasive disease (Spuijbroek et al. 1992, Foidart et al. 1993). In vitro experiments also imply that endometriotic cells are invasive and able to metastasize. Analogous to tumor metastasis, it is likely that cell adhesion molecules are central for the invasion and metastasis of endometriotic cells.

Cadherins are a family of adhesion molecules that mediate $\mathrm{Ca}^{2+}$-dependent cell-cell adhesion in all solid tissues of an organism and modulate a wide variety of processes, including cell polarization and migration (Takeichi 1987, 1990, Wheelock \& Johnson 2003). E-cadherin, an epithelial cellular junction protein expressed in almost all epithelial cells (Shimoyama et al. 1989), is among the best understood of the cadherins and plays an important role in the maintenance of epithelial development, organization, and cell integrity. The loss of E-cadherin, a metastasis suppressor molecule in carcinomas, is associated with tumor progression and metastases formation in a series of different cancers (Frixen et al. 1991, Birchmeier \& Behrens 1994, Huiping et al. 2001, Yoshida et al. 2001). Is it possible that E-cadherin could also act as an invasion-suppressor molecule in endometriosis? Indeed, primary cells from human endometriotic biopsies but not from human endometrial biopsies were invasive in an in vitro collagen invasion assay. These in vitro invasive endometriotic cells were found to be nonmalignant epithelial cells lacking E-cadherin (Gaetje et al. 1997). Moreover, E-cadherin was slightly reduced in eutopic endometrium and significantly decreased in ectopic biopsies of endometriosis patients as compared with that in eutopic endometrium of unaffected women 
(Starzinski-Powitz et al. 1999, Poncelet et al. 2002). Therefore, the loss of E-cadherin expression may constitute a crucial mechanism in the pathogenesis of endometriosis.

The E-cadherin gene is polymorphic; two adjacent SNPs $(-160 \mathrm{C} \rightarrow \mathrm{A}$ and $-347 \mathrm{G} \rightarrow \mathrm{GA})$ at upstream positions from the transcriptional start site of the promoter and a single base change from $\mathrm{C}$ to $\mathrm{T}$ at position +54 after the stop codon of the gene were identified (Becker et al. 1995, Li et al. 2002, Nakamura et al. 2002). These polymorphisms were associated with the development and progression of a certain cancer (Verhage et al. 2002, Shin et al. 2004a, $\mathrm{Wu}$ et al. 2005). The relation between E-cadherin gene polymorphisms and the risk of developing endometriosis has not been reported. In this paper, we studied three polymorphisms $(-160 \mathrm{C} \rightarrow \mathrm{A},-347$ $\mathrm{G} \rightarrow \mathrm{GA}$, and $3^{\prime}$-UTR $+54 \mathrm{C} \rightarrow \mathrm{T}$ ) in the E-cadherin gene in association with the risk of developing endometriosis, in North China.

\section{Materials and Methods}

\section{Study participants}

Blood was obtained from the following two groups and DNA was extracted for genotyping: $(\pi)$ healthy female blood donors aged $25-51$ years $(n=189)$ and $(\theta)$ in patients for endometriosis in the Fourth Hospital, Hebei Medical University between 2001 and $2005(n=152)$. The patients were all clinically, endoscopically, and histologically confirmed. All of the endometriosis patients who had not undertaken treatment with hormones were in stages III and IV. Patients were staged according to the revised American Fertility Society (1985) classification. General information on all patients was recorded in detail in the medical chart.

The control group consisted of women of reproductive age without any malignant disease, which was confirmed by surgical exploration at voluntary abortion, cesarean section, or pathologically after hysterectomy was performed for dysfunctional uterine bleeding. The general information on the healthy controls was extracted from their medical chart. All of the subjects were women of the Han nationality in North China. The Ethics Committee of Hebei Obstetrics and Gynecology Institute approved the study and informed consent was obtained from all recruited subjects.

\section{DNA extraction}

Venous blood ( $5 \mathrm{ml}$ ) was drawn from each subject into Vacutainer tubes containing EDTA and stored at $4{ }^{\circ} \mathrm{C}$. Genomic DNA was extracted within 1 week after sampling using proteinase $\mathrm{K}$ (Merck) digestion followed by a salting out procedure according to the method of Miller et al. (1988).

\section{E-cadherin - $160 C \rightarrow A,-347 G \rightarrow G A$, and $3^{\prime}$-UTR $C \rightarrow T$ genotyping}

The E-cadherin $-160 \mathrm{C} \rightarrow \mathrm{A},-347 \mathrm{G} \rightarrow \mathrm{GA}$, and +54 $\mathrm{C} \rightarrow \mathrm{T}$ genotypes were determined by PCR-restriction fragment length polymorphism assay. The primers for amplifying the E-cadherin promoter fragment were 5'-CGCCCCGACTTGTCTCTCTAC-3' (forward) and 5'-GGCCACAGCCAATCA GCA-3' (backward) and for the $+54 \mathrm{C} \rightarrow \mathrm{T}$ SNP at the E-cadherin $3^{\prime}$ UTR were 5'-CAGACAAAGACCAGGACTAT-3' (forward) and 5'-AAGGGAGCTGA AAAACCACCAGC-3' (backward). The PCR was performed in a $25 \mu \mathrm{l}$ volume containing $100 \mathrm{ng}$ DNA template, $2.5 \mu \mathrm{l}$ of $10 \times$ PCR buffer, $1.5 \mu \mathrm{l}$ of $25 \mathrm{mmol} / \mathrm{I} \mathrm{MgCl}_{2}, 2.5 \mathrm{U}$ Taq DNA polymerase (BioDev-Tech., Beijing, China), $0.5 \mu \mathrm{l}$ of $10 \mathrm{mmol} / \mathrm{l}$ dNTPs, and $200 \mathrm{nM}$ each primer. The PCR cycling conditions were 5 min at $94{ }^{\circ} \mathrm{C}$ followed by 35 cycles of $30 \mathrm{~s}$ at $94^{\circ} \mathrm{C}, 30 \mathrm{~s}$ at $66^{\circ} \mathrm{C}$ for C-160 A and G-347 GA, $30 \mathrm{~s}$ at $56^{\circ} \mathrm{C}$ for $+54 \mathrm{C} \rightarrow \mathrm{T}$, and $60 \mathrm{~s}$ at $72{ }^{\circ} \mathrm{C}$, with a final step at $72{ }^{\circ} \mathrm{C}$ for $10 \mathrm{~min}$ to allow for the complete extension of all PCR fragments. The PCR product was $448 \mathrm{bp}$ for the E-cadherin promoter and two $8 \mu \mathrm{l}$ aliquots were subjected to digestion at $37^{\circ} \mathrm{C}$ overnight in a $10 \mu \mathrm{l}$ reaction containing $10 \mathrm{U}$ Hincll (SBS Genetech Co. Ltd, Beijing, China) or 10 U Banll (TakaRa Biotechnology Co. Ltd, Dalian, China). After digestion, the products were separated on a $3 \%$ agarose gel that was stained with ethidium bromide. For the $-160 \mathrm{C} \rightarrow$ A polymorphism, the $A$ alleles were represented by DNA bands with sizes of 368 and $80 \mathrm{bp}$ and the $C$ alleles were represented by a DNA band with a size of $448 \mathrm{bp}$, whereas the heterozygotes displayed a combination of both alleles (448, 368, and $80 \mathrm{bp}$; Fig. 1). For the $-347 \mathrm{G} \rightarrow \mathrm{GA}$ polymorphism, the GA alleles were represented by DNA bands with sizes of 332 and $116 \mathrm{bp}$ and the $\mathrm{G}$ alleles were represented by a DNA band with sizes of 263, 116, and $68 \mathrm{bp}$, whereas the heterozygotes displayed a combination of both alleles $(332,263,116$, and $68 \mathrm{bp}$; Fig. 2). The PCR product of the $3^{\prime}-U T R \quad C \rightarrow T$ polymorphism in the E-cadherin $3^{\prime}$ UTR was $172 \mathrm{bp}$. After digestion by Pmacl (TakaRa Biotechnology Co. Ltd), the products were separated on a $3 \%$ agarose gel that was stained with ethidium bromide. As a result, the 3'-UTR Talleles were represented by a DNA band with a

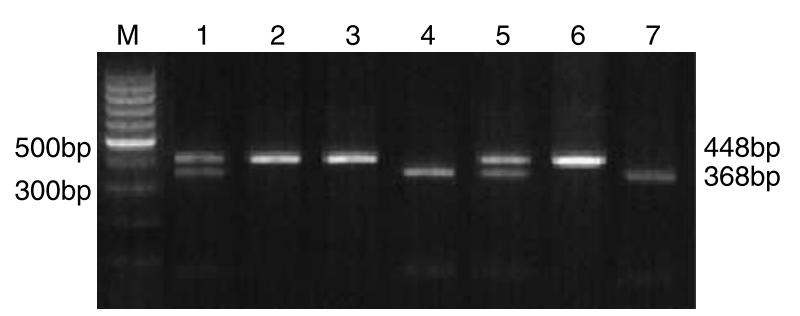

Figure $1 \mathrm{E}$-cadherin $-160 \mathrm{bp} \mathrm{C} \rightarrow$ A genotyping by PCR-RFLP analysis followed by separation on $3 \%$ agarose gel as described in the text. Lane $M=100$ bp ladder; lanes 2,3 , and $6=\mathrm{C} / \mathrm{C}$; lanes 1 and $5=\mathrm{C} / \mathrm{A}$; lanes 4 and $7=\mathrm{A} / \mathrm{A}$. 


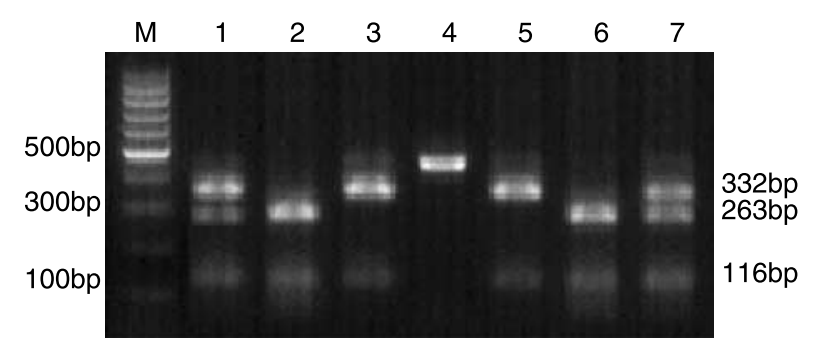

Figure 2 E-cadherin -347 bp $\mathrm{G} \rightarrow \mathrm{GA}$ genotyping by PCR-RFLP analysis followed by separation on $3 \%$ agarose gel as described in the text. Lane $M=100$ bp ladder; lanes 3 and $5=\mathrm{GA} / \mathrm{GA}$; lanes 1 and $7=\mathrm{G} / \mathrm{GA}$; lanes 2 and $6=\mathrm{G} / \mathrm{G}$; lane $4=\mathrm{PCR}$ product.

size of $172 \mathrm{bp}$ and the $3^{\prime}$-UTR C alleles were represented by DNA bands with sizes of 146 and 26 bp, whereas the heterozygotes displayed a combination of both alleles (172, 146, and 26 bp; Fig. 3).

For a negative control, distilled water was used instead of DNA in the reaction system for each panel of PCR. The PCRs of $10 \%$ of the samples were run in duplicate for quality control.

\section{Statistical analysis}

Statistical analysis was performed using the SPSS10.0 software package (SPSS Inc., Chicago, IL, USA). HardyWeinberg analysis was performed to compare the observed and expected genotype frequencies using the $\chi^{2}$ test. A comparison of the E-cadherin $-160 \mathrm{C} \rightarrow \mathrm{A}$, $-347 \mathrm{G} \rightarrow \mathrm{GA}$, and 3'-UTR C $\rightarrow$ T genotype distributions in the study groups was performed by means of twosided contingency tables using the $\chi^{2}$ test. The E-cadherin $-160 \mathrm{C} \rightarrow \mathrm{A}$ and $-347 \mathrm{G} \rightarrow$ GA haplotype frequencies and linkage disequilibrium coefficients were estimated using the EH linkage software (version 1.2, Rockefeller University, New York, NY, USA). The odds ratio $(\mathrm{OR})$ and $95 \%$ confidence interval $(\mathrm{Cl})$ were calculated using an unconditional logistic regression model and adjusted by age accordingly. A probability level of $5 \%$ was considered significant.

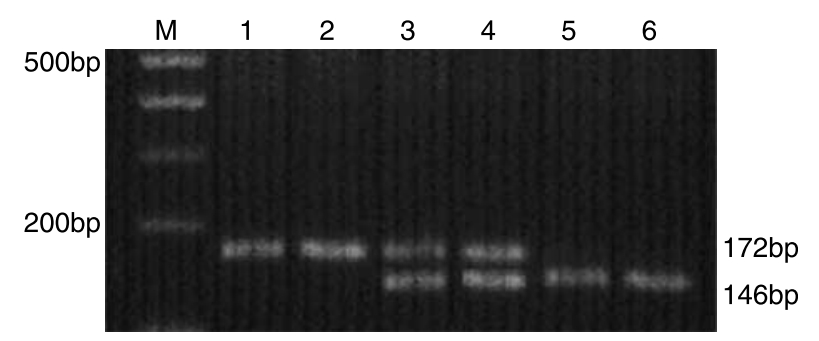

Figure 3 E-cadherin $3^{\prime}$-UTR $\mathrm{C} \rightarrow \mathrm{T}$ genotyping by PCR-RFLP analysis followed by separation on $3 \%$ agarose gel as described in the text. Lane $M=100$ bp ladder; lane $2=\mathrm{T} / \mathrm{T}$; lanes 3 and $4=\mathrm{C} / \mathrm{T}$; lanes 5 and $6=\mathrm{C} / \mathrm{C}$; lane $1=\mathrm{PCR}$ product.

\section{Results}

Association of E-cadherin $-160 C \rightarrow A,-347 G \rightarrow G A$, and $3^{\prime}$-UTR $C \rightarrow T S N P$ with susceptibility to endometriosis

The distribution of the E-cadherin $-160 \mathrm{C} \rightarrow \mathrm{A},-347$ $\mathrm{G} \rightarrow \mathrm{GA}$, and $3^{\prime}$-UTR $\mathrm{C} \rightarrow \mathrm{T}$ genotypes in the control group did not significantly deviate from that expected for a Hardy-Weinberg equilibrium $\left(\chi^{2}=0.33,0.14\right.$, and 2.65 respectively and $P=0.57,0.70$, and 0.10 respectively). There was no significant difference in genotype and allelotype distribution of the E-cadherin $-160 \mathrm{C} \rightarrow$ A SNP between endometriosis patients and controls (Table 1, all $P$ values 0.05 ). When compared with the $\mathrm{C} /$ $C$ genotype, the carriers of the ' $A$ ' allele were not significantly susceptible to developing endometriosis. The OR was $0.82(95 \% \mathrm{Cl}=0.52-1.29$; Table 2$)$.

The frequencies of the three genotypes and two allelotypes of E-cadherin - $347 \mathrm{G} \rightarrow \mathrm{GA}$ in endometriosis patients were not different from those in controls (Table 1, all $P$ values $>0.05$ ). When compared with the $\mathrm{G} / \mathrm{G}$ genotype, the $\mathrm{G} / \mathrm{GA}+\mathrm{GA} / \mathrm{GA}$ genotypes did not significantly influence the risk of developing endometriosis. The OR was $1.20(95 \% \mathrm{Cl}=0.78-1.84$; Table 2$)$.

There were significant differences in genotype and allelotype distribution of the E-cadherin $3^{\prime}$-UTR $\mathrm{C} \rightarrow \mathrm{T}$ between endometriosis patients and controls (Table 1 , all $P$ values $<0.05)$. The distribution of the $\mathrm{C} / \mathrm{C}$ genotype in endometriosis patients $(57.9 \%)$ was higher than that in the controls $(43.4 \%)$. When compared with the $\mathrm{T} / \mathrm{T}+\mathrm{C} / \mathrm{T}$ genotypes, the $\mathrm{C} / \mathrm{C}$ genotype significantly increased the risk of development of endometriosis. The OR was 1.79 $(95 \% \mathrm{Cl}=1.17-2.76$; Table 2).

Table 1 Distribution of genotypes and alleles of three single nucleotide polymorphisms in E-cadherin genes.

\begin{tabular}{|c|c|c|c|c|}
\hline Gene & $\begin{array}{c}\text { Genotype/ } \\
\text { allele }\end{array}$ & $\begin{array}{c}\text { Controls, } \\
\text { no. } \\
\text { (frequency) }\end{array}$ & $\begin{array}{c}\text { Endome } \\
\text { triosis, no. } \\
\text { (frequency) }\end{array}$ & $\boldsymbol{P}\left(\chi^{2}\right.$ test $)$ \\
\hline \multicolumn{5}{|c|}{ E-cadherin $-160 \mathrm{C} \rightarrow \mathrm{A}$} \\
\hline \multirow[t]{3}{*}{ Genotype } & $\mathrm{C} / \mathrm{C}$ & $121(64.0)$ & $104(68.4)$ & \\
\hline & $\mathrm{C} / \mathrm{A}$ & $62(32.8)$ & 45 (29.6) & 0.61 \\
\hline & $\mathrm{A} / \mathrm{A}$ & $6(3.2)$ & $3(2.0)$ & \\
\hline \multirow[t]{2}{*}{ Allelotype } & C & $304(80.4)$ & $253(83.2)$ & 0.35 \\
\hline & A & $74(19.6)$ & $51(16.8)$ & \\
\hline \multicolumn{5}{|c|}{ E-cadherin $-347 \mathrm{G} \rightarrow \mathrm{GA}$} \\
\hline \multirow[t]{3}{*}{ Genotype } & $\mathrm{G} / \mathrm{G}$ & $108(57.1)$ & $80(52.6)$ & 0.26 \\
\hline & $\mathrm{G} / \mathrm{GA}$ & $71(37.6)$ & $57(37.5)$ & \\
\hline & GA/GA & $10(5.3)$ & $15(9.9)$ & \\
\hline \multirow[t]{2}{*}{ Allelotype } & G & 287 (75.9) & $217(71.4)$ & 0.18 \\
\hline & GA & $91(24.1)$ & 87 (28.6) & \\
\hline \multicolumn{5}{|c|}{ E-cadherin $3^{\prime}$-UTR $\mathrm{C} \rightarrow \mathrm{T}$} \\
\hline \multirow[t]{3}{*}{ Genotype } & $\mathrm{C} / \mathrm{C}$ & $82(43.4)$ & $88(57.9)$ & 0.01 \\
\hline & $\mathrm{C} / \mathrm{T}$ & $77(40.7)$ & $40(26.3)$ & \\
\hline & $\mathrm{T} / \mathrm{T}$ & $30(15.9)$ & $24(15.8)$ & \\
\hline \multirow[t]{2}{*}{ Allelotype } & $\mathrm{C}$ & $241(63.8)$ & $216(71.1)$ & 0.04 \\
\hline & $\mathrm{T}$ & $137(36.2)$ & $88(28.9)$ & \\
\hline
\end{tabular}


Table 2 Association of three single nucleotide polymorphisms in $E$ cadherin gene with the risk of endometriosis development.

\begin{tabular}{lcccl}
\hline Gene & Genotype & $\begin{array}{c}\text { Controls } \\
(n)\end{array}$ & $\begin{array}{c}\text { Endome- } \\
\text { triosis }(n)\end{array}$ & OR $(95 \% \mathrm{Cl})$ \\
\hline$-160 \mathrm{C} \rightarrow \mathrm{A}$ & $\mathrm{C} / \mathrm{C}$ & 121 & 104 & \\
& $\mathrm{C} / \mathrm{A}+\mathrm{A} / \mathrm{A}$ & 68 & 48 & 0.82 \\
& & & & $(0.52-1.29)^{\mathrm{a}}$ \\
$-347 \mathrm{G} \rightarrow \mathrm{GA}$ & $\mathrm{G} / \mathrm{G}$ & 108 & 80 & \\
& $\mathrm{G} / \mathrm{GA}+$ & 81 & 72 & 1.20 \\
& $\mathrm{GA} / \mathrm{GA}$ & & & $(0.78-1.84)^{\mathrm{b}}$ \\
$3^{\prime}-$ UTR $\mathrm{C} \rightarrow \mathrm{T}$ & $\mathrm{T} / \mathrm{T}+\mathrm{C} / \mathrm{T}$ & 107 & 64 & 1.79 \\
& $\mathrm{C} / \mathrm{C}$ & 82 & 88 & $(1.17-2.76)^{\mathrm{c}}$ \\
& & & & \\
\hline
\end{tabular}

${ }^{\mathrm{a}}$ The odds ratio of the $\mathrm{C} / \mathrm{A}+\mathrm{A} / \mathrm{A}$ genotype against the $\mathrm{C} / \mathrm{C}$ genotype for $-160 \mathrm{C} \rightarrow$ A polymorphism. ${ }^{\mathrm{b}}$ The odds ratio of the G/GA $+\mathrm{GA} / \mathrm{GA}$ genotype against the $\mathrm{C} / \mathrm{C}$ genotype for $-347 \mathrm{G} \rightarrow \mathrm{GA}$ polymorphism. ${ }^{\mathrm{C}}$ The odds ratio of the $\mathrm{C} / \mathrm{C}$ genotype against the $\mathrm{T} / \mathrm{T}+\mathrm{C} / \mathrm{T}$ genotype for 3'-UTR C $\rightarrow$ T polymorphism.

\section{Haplotype of E-cadherin $-160 C \rightarrow A$ and $-347 G \rightarrow$ $G A$, two SNPs with susceptibility to endometriosis}

The results of the $2 \mathrm{LD}$ program analysis showed that the E-cadherin $-160 \quad \mathrm{C} \rightarrow \mathrm{A}$ and $-347 \quad \mathrm{G} \rightarrow \mathrm{GA}$ polymorphisms displayed linkage disequilibrium $\left(\mathrm{D}^{\prime}=0.999\right)$. The $-160 \mathrm{C} /-347 \mathrm{G}$ was the most common haplotype in the control women (56.4\%), followed by the $-160 \mathrm{C} /-347 \mathrm{GA}(24.0 \%)$ and -160 $\mathrm{A} /-347 \mathrm{G}(19.6 \%)$ haplotypes. The $-160 \mathrm{~A} /-347$ GA haplotype was only detected in endometriosis patients $(2 \%)$. When compared with the most common haplotype of $-160 \mathrm{C} /-347 \mathrm{G}$, the haplotypes of -160 $\mathrm{C} /-347 \mathrm{GA}$ and $-160 \mathrm{~A} /-347 \mathrm{G}$ were not significantly indicative of the risk of endometriosis (Table 3 ).

\section{Discussion}

In the present study, we focused on the significance of E-cadherin polymorphisms to the risk of developing endometriosis. The results showed that there is no association between the $-160 \mathrm{C} \rightarrow \mathrm{A}$ and $-347 \mathrm{G} \rightarrow$ GA polymorphisms at the E-cadherin gene promoter region and the risk of developing endometriosis. However, the haplotype of $-160 \mathrm{C} /-347 \mathrm{GA}$ and the $3^{\prime}$-UTR $\mathrm{C} \rightarrow \mathrm{T}$ polymorphism of the E-cadherin gene

Table 3 Haplotypes of $-160 \mathrm{C} \rightarrow \mathrm{A}$ and $-347 \mathrm{G} \rightarrow \mathrm{GA}$ SNP in $E$-cadherin gene with the risk of endometriosis development.

\begin{tabular}{lccc}
\hline Haplotype & Control $n(\%)$ & $\begin{array}{c}\text { Endometriosis } \\
n(\%)\end{array}$ & OR $(95 \% \mathrm{Cl})$ \\
\hline C/G & $213(56.4)$ & $172(56.6)$ & \\
A/G & $74(19.6)$ & $45(14.8)$ & $0.75(0.49-1.15)^{\mathrm{a}}$ \\
C/GA & $91(24.0)$ & $81(26.6)$ & $1.10(0.77-1.58)^{\mathrm{b}}$ \\
A/GA & $0(0)$ & $6(2.0)$ & \\
\hline
\end{tabular}

${ }^{a}$ The odds ratio of the $\mathrm{A} / \mathrm{G}$ haplotype against the $\mathrm{C} / \mathrm{G}$ haplotype in endometriosis. ${ }^{\mathrm{b}}$ The odds ratio of the C/GA haplotype against the $\mathrm{C} / \mathrm{G}$ haplotype in endometriosis. were associated with the risk of endometriosis. The $-160 \mathrm{C} /-347$ GA haplotype and $3^{\prime}$-UTR C/C homozygote indicated a relatively higher risk for developing endometriosis than other genotypes.

The $-160 \mathrm{C} \rightarrow \mathrm{A}$ and $-347 \mathrm{G} \rightarrow \mathrm{GA}$ are two common SNPs upstream from the transcriptional start site of the E-cadherin gene and have a significant effect on the transcriptional activity in transient transfection studies. Several major cis-acting elements have been identified within a short section of the proximal promoter. Among these are the two E boxes, a CAAT box and a SP1-binding site (Giroldi et al. 1997). The E-cadherin gene promoter thus exhibits a modular structure, suggesting that the strict control of epithelium-specific E-cadherin expression might result from interactions among the various regulatory elements (Behrens et al. 1991). Therefore, the molecular mechanism of differential transcriptional activity may be well explained as a difference in affinity of the DNAbinding protein(s) to the two allelic forms of the E-cadherin promoter. The ' $\mathrm{A}$ ' allele of the $-160 \mathrm{C} \rightarrow$ A polymorphism decreased the transcriptional efficiency by $68 \%$ when compared with the $C$ allele (Li et al. 2002). The 'GA' allele of the $-347 \mathrm{G} \rightarrow \mathrm{GA}$ polymorphism decreased the transcriptional efficiency by tenfold when compared with the ' $G$ ' allele (Shin et al. 2004a). The $-160 \mathrm{C} \rightarrow \mathrm{A}$ and $-347 \mathrm{G} \rightarrow \mathrm{GA}$ allelic variation may be a potential genetic marker that can help identify individuals at a higher risk for invasive/metastatic diseases.

Recently, studies have investigated the association between the E-cadherin $-160 \mathrm{C} \rightarrow$ A polymorphism and the risk of several types of cancer but the results were mixed. Verhage et al. (2002) found that ' $A$ ' allele carriers had a higher risk of prostate cancer when compared with ' $C$ ' allele carriers. Jonsson et al. (2004) studied Swedish patients with hereditary prostate cancer and also found a higher risk among ' $\mathrm{A}$ ' allele carriers. However, there was no association between the E-cadherin $-160 \mathrm{C} \rightarrow \mathrm{A}$ polymorphism and the occurrence or progression of prostate cancer in Japanese populations (Tsukino et al. 2004). In a study of gastric cancer, Park et al. (2003) suggested that the $-160 \mathrm{C} \rightarrow \mathrm{A}$ polymorphism of E-cadherin has no direct effect on the risk of development of gastric cancer and its histological classification. However, the Wu et al. (2002) study suggested that individuals with the $-160 \mathrm{~A} / \mathrm{A}$ genotype of E-cadherin have a decreased risk of gastric carcinoma. The E-cadherin $-347 \mathrm{G} \rightarrow \mathrm{GA}$ polymorphism has been reported to be associated with risk of developing familial gastric cancer and sporadic colorectal cancers (Shin et al. 2004a, 2004b). The GA allele may be a risk factor for certain cancers.

In this paper, our study showed that there was no significant difference in the frequencies of the E-cadherin $-160 \mathrm{C} \rightarrow \mathrm{A}$ and $-347 \mathrm{G} \rightarrow \mathrm{GA}$ polymorphism genotypes between endometriosis and controls. However, the result shows a significant linkage disequilibrium between the $-160 \mathrm{C} \rightarrow \mathrm{A}$ and the $-347 \mathrm{G} \rightarrow \mathrm{GA}$ 
polymorphisms, i.e. the $-160 \mathrm{C}$ allele tended to be linked to the $-374 \mathrm{G}$ allele. The $-160 \mathrm{C} /-374 \mathrm{G}$ was the most common haplotype in healthy women of North China (56.4\%). The frequency of the $-160 \mathrm{G} /-374 \mathrm{GA}$ haplotype was $0 \%$ in the control group and $2 \%$ in endometriosis patients. The $-160 \mathrm{G} /-374 \mathrm{GA}$ haplotype may be a risk factor for developing endometriosis because the $-160 \mathrm{G}$ and $-374 \mathrm{GA}$ alleles were associated with decreased transcriptional efficiency of the E-cadherin gene. However, this result needs to be further tested in larger studies of endometriosis patients.

The $\mathrm{C} \rightarrow$ T polymorphism is located at nucleotide 2797 of the E-cadherin cDNA sequence, 54 nucleotides downstream from the TAG stop codon. Although the function of the 3'-UTR + 54 C $\rightarrow$ T polymorphism was unclear, studies have showed that this polymorphism was associated with cancer and other diseases (Tsai et al. 2003, Wu et al. 2005, Lin et al. 2006). Wu et al. found that the 'CC' homozygote indicates a relatively higher risk for developing prostate cancer than other genotypes (Lin etal. 2006). Our study also showed that the frequency of the ' $\mathrm{CC}^{\prime}$ homozygote in endometriosis patients $(57.9 \%)$ was higher than that in controls (43.4\%) and the ' $\mathrm{CC}$ ' homozygote carriers had a higher incidence of developing endometriosis (1.79-fold) than those who do not. Our other study was consistent with this paper, which suggested that the ' $C C^{\prime}$ ' homozygote was a high risk factor for the development of gastric cardiac adenocarcinoma and ovarian cancer. In addition, the E-cadherin protein expression of ovarian cancer patients with CC genotype was significantly lower than that of the ones with CT or TT genotype ( $P=0.017$; unpublished results). As we know, the 3'-UTR is not the translated area of the protein, but it may be associated with mRNA stability of the transcript. The understanding of the E-cadherin gene 3'-UTR is limited. The Keirsebilck et al. (1998) in vitro study revealed that the downregulation of E-cadherin protein expression was caused by mRNA instability that was triggered by particular 3'-UTR sequences. Moreover, there are many examples where the $3^{\prime}-$ UTR may change the expression of genes, such as the TYMS gene that contains a 6 bp deletion/insertion in the $3^{\prime}$-UTR that affects the TYMS mRNA stability and translation (Ulrich et al. 2000). The polymorphism of the 3'-UTR in the CYP2A6gene played an important role in CYP2A6 mRNA stabilization and enzyme expression. Such polymorphisms have been described to influence the in vivo rate of nicotine elimination and possibly the cigarette consumption and risk of smokinginduced lung cancer (Wang et al. 2006). Although we are not going to conclude that the ' $\mathrm{C}$ ' allele of the E-cadherin gene $3^{\prime}$-UTR polymorphism is the direct cause of endometriosis, we can indicate that there is an association. These findings suggest that the $3^{\prime}$-UTR C $\rightarrow$ T polymorphism may play a role in the etiology of endometriosis.

The etiology of endometriosis is uncertain, but implantation of viable endometrium refluxed into the peritoneal cavity during menstruation is a major theory (Thomas 1993). Since retrograde menstruation is a very common phenomenon among women of reproductive age, there must be other factors that contribute to the pathophysiology and/or the pathogenesis of endometriosis. Genetic predisposition is believed to play a significant role in the establishment and maintenance of endometriosis. Whether the differential expression of E-cadherin between eutopic endometrium and ectopic biopsies of endometriosis patients and those of unaffected women is related to genetic factors that are associated with the risk for developing endometriosis is important for understanding the mechanism of endometriosis.

To the best of our knowledge, this is the first study to look for an association between the polymorphisms of the E-cadherin gene and the risk of developing endometriosis. Our study results suggest that certain genetic polymorphisms of the E-cadherin gene seem to be correlated with a risk of developing endometriosis. Further, larger population-based studies as well as functional evaluation of the variants are warranted to confirm our findings.

\section{Acknowledgement}

The authors declare that there is no conflict of interest that would prejudice the impartiality of this scientific work.

\section{References}

Becker KF, Reich U, Schott C \& Hofler H 1995 Single superoxide nucleotide polymorphisms in the human E-cadherin gene. Human Genetics 96 739-740.

Behrens J, Lowrick O, Klein-hitpass L \& Birchmeier W 1991 The E-cadherin promoter: functional analysis of a G.C-rich region and an epithelial cell-specific palindromic regulatory element. PNAS $\mathbf{8 8}$ 11495-11499.

Birchmeier W \& Behrens J 1994 Cadherin expression in carcinomas: role in the formation of cell junctions and the prevention of invasiveness. Biochimica et Biophysica Acta 27 11-26.

Foidart JM, Beliard A \& Donnez J 1993 In Endometriosis and Invasion. Current Status of Endometriosis. Research and Management, pp 35-39. Eds I Brosens \& J Donnez. New York: Parthenon Publishing Group.

Frixen UH, Behrens J, Sachs M, Eberle G, Voss B, Warda A, Lochner D \& Birchmeier W 1991 E-cadherin-mediated cell-cell adhesion prevents invasiveness of human carcinoma cells. Journal of Cell Biology 113 173-185.

Gaetje R, Kotzian S, Herrmann G, Baumann R \& Starzinski-Powitz A 1997 Nonmalignant epithelial cells, potentially invasive in human endometriosis, lack the tumor suppressor molecule E-cadherin. American Journal of Pathology 150 461-467.

Giroldi LA, Bringuier PP, de Weijert M, Jansen C, van Bokhoven A \& Schalken JA 1997 Role of E boxes in the repression of E-cadherin expression. Biochemical and Biophysical Research Communications 241 453-458.

Huiping C, Kristjansdottir S, Jonasson JG, Magnusson J, Egilsson V \& Ingvarsson S 2001 Alterations of E-cadherin and $\beta$-catenin in gastric cancer. BMC Cancer 116.

Jonsson BA, Adami HO, Hagglund M, Bergh A, Goransson I, Stattin P, Wiklund F \& Gronberg H $2004-160 \mathrm{C} / \mathrm{A}$ polymorphism in the $E$ cadherin gene promoter and risk of hereditary, familial and sporadic prostate cancer. International Journal of Cancer 109 348-352. 
Keirsebilck A, Van Hoorde L, Gao Y, De Bruyne G, Bruyneel E, Vermassen P, Mareel M \& van Roy F 1998 Mechanisms of downregulation of transfected $\mathrm{E}$-cadherin $\mathrm{CDNA}$ during formation of invasive tumors in syngeneic mice. Invasion and Metastasis 18 44-56.

Li LC, Chui RM, Sasaki M, Nakajima K, Perinchery G, Au HC, Nojima D, Carroll P \& Dahiya R 2002 A single nucleotide polymorphism in the $E$-cadherin gene promoter alters transcriptional activities. Cancer Research 60 873-876.

Lin HJ, Tsai FJ, Hung P, Chen WC, Chen HY, Fan SS \& Tsai SW 2006 Association of E-cadherin gene $3^{\prime}$-UTR C/T polymorphism with primary open angle glaucoma. Ophthalmic Research 38 44-48.

Miller SA, Dybes DD \& Polesky HF 1988 A simple salting out procedure for extracting DNA from human nucleated cells. Nucleic Acids Research 161215.

Nakamura A, Shimazaki T, Kaneko K, Shibata M, Matsumura T, Nagai M, Makino R \& Mitamura K 2002 Characterization of DNA polymorphisms in the E-cadherin gene $(\mathrm{CDH} 1)$ promoter region. Mutation Research 502 19-24.

Park WS, Cho YG, Park JY, Kim CJ, Lee JH, Kim HS, Lee JW, Song YH, Park CH, Park YK et al. 2003 A single nucleotide polymorphism in the E-cadherin gene promoter-160 is not associated with risk of Korean gastric cancer. Journal of Korean Medical Science $\mathbf{1 8}$ 501-504.

Poncelet C, Leblanc M, Walker-Combrouze F, Soriano D, Feldmann G, Madelenat P, Scoazec JY \& Darai E 2002 Expression of cadherins and CD44 isoforms in human endometrium and peritoneal endometriosis. Acta Obstetricia et Gynecologica Scandinavica 81 195-203.

Scotti S, Regidor PA, Schindler AE \& Winterhager E 2000 Reduced proliferation and cell adhesion in endometriosis. Molecular Human Reproduction 6 610-617.

Shimoyama Y, Hirohashi S, Hirano S, Noguchi M, Shimosato Y, Takeichi M \& Abe O 1989 Cadherin cell-adhesion molecules in human epithelial tissues and carcinomas. Cancer Research 49 2128-2133.

Shin Y, Kim IJ, Kang HC, Park JH, Park HR, Park HW, Park MA, Lee JS, Yoon KA, Ku JL et al. 2004a The E-cadherin -347G $\rightarrow$ GA promoter polymorphism and its effect on transcriptional regulation. Carcinogenesis 25 895-899.

Shin Y, Kim IJ, Kang HC, Park JH, Park HW, Jang SG, Lee MR, Jeong SY, Chang HJ, Ku JL et al. 2004b A functional polymorphism (-347 $\mathrm{G} \rightarrow \mathrm{GA}$ ) in the $E$-cadherin gene is associated with colorectal cancer. Carcinogenesis 25 2173-2176.

Spuijbroek MD, Dunselman GA, Menheere PP \& Evers JL 1992 Early endometriosis invades the extracellular matrix. Fertility and Sterility 58 929-933.

Starzinski-Powitz A, Handrow-Metzmacher H \& Kotzian S 1999 The putative role of cell adhesion molecules in endometriosis: can we learn from tumour metastasis? Molecular Medicine Today 5 304-309.
Takeichi M 1987 Cadherins: a molecular family essential for selective cell-cell adhesion and animal morphogenesis. Trends in Genetics 3 213-217.

Takeichi M 1990 Cadherins: a molecular family important in selective cell-cell adhesion. Annual Review of Biochemistry 59 237-252.

Thomas EJ 1993 Endometriosis. BMJ 306 158-159.

Tsai FJ, Wu HC, Chen HY, Lu HF, Hsu CD \& Chen WC 2003 Association of E-cadherin gene $3^{\prime}-\mathrm{UTR} \mathrm{C} / \mathrm{T}$ polymorphism with calcium oxalate stone disease. Urologia Internationalis 70 278-281.

Tsukino H, Kuroda Y, Imai H, Nakao H, Qiu D, Komiya Y, Inatomi H, Hamasaki T, Kohshi K, Osada Y et al. 2004 Lack of evidence for the association of $E$-cadherin gene polymorphism with increased risk or progression of prostate cancer. Urologia Internationalis 72 203-207.

Ulrich CM, Bigler J, Velicer CM, Greene EA, Farin FM \& Potter JD 2000 Searching expressed sequence tag databases: discovery and confirmation of a common polymorphism in the thymidylate synthase gene. Cancer Epidemiology, Biomarkers and Prevention 9 1381-1385.

Verhage BA, van Houwelingen K, Ruijter TE, Kiemeney LA \& Schalken JA 2002 Single-nucleotide polymorphism in the E-cadherin gene promoter modifies the risk of prostate cancer. International Journal of Cancer 100 683-685.

Wang J, Pitarque M \& Ingelman-Sundberg M 2006 3'-UTR polymorphism in the human CYP2A6 gene affects mRNA stability and enzyme expression. Biochemical and Biophysical Research Communications 10 491-497.

Wheelock MJ \& Johnson KR 2003 Cadherins as modulators of cellular phenotype. Annual Review of Cell and Developmental Biology 19 207-235.

Wu MS, Huang SP, Chang YT, Lin MT, Shun CT, Chang MC, Wang HP, Chen CJ \& Lin JT 2002 Association of the $-160 \mathrm{C} \rightarrow$ a promoter polymorphismE-cadherin. Cancer 94 1443-1448.

Wu HC, Lai MT, Wu CI, Chen HY, Wan L, Tsai FJ \& Chen WC 2005 E-cadherin gene $3^{\prime}$-UTR C/T polymorphism is associated with prostate cancer. Urologia Internationalis 75 335-350.

Yoshida R, Kimura N, Harada Y \& Ohuchi N 2001 The loss of E-cadherin, $\alpha$ - and $\beta$-catenin expression is associated with metastasis and poor prognosis in invasive breast cancer. International Journal of Oncology 18 513-520.

Received 27 February 2007

First decision 29 March 2007

Revised manuscript received 8 May 2007

Accepted 9 May 2007 